\title{
A propagação da paz: um constante desafio às religiões
}

\section{KÜNG, Hans. Uma ética global para a política e a economia mundiais.} Tradução Carlos Almeida Pereira. Petrópolis: Vozes, 1999.

Elisângela de Carvalho Franco Instituto Federal de Educação, Ciência e Tecnologia de Rondônia

Atualmente, tem-se notado que a maior parte dos conflitos entre as civilizações tem sido gerada por questões ou fatores religiosos, culminando com a perturbação do ethos mundial e, consequentemente, com a paz mundial. Essa constatação se dá, devido a vários acontecimentos, ocorridos por conflitos religiosos. Mas, o que as religiões têm feito para mudar esse triste paradigma tão presente na contemporaneidade dos novos tempos?

O que é perceptível, na obra de Küng, Uma etica global para a política e a economia mundiais, traduzida por Carlos Almeida Pereira e publicada pela Editora Vozes em 1999, é a sua relevante observação, quando menciona que, em nome da religião, pode-se cometer várias atrocidades, até inspirar e legitimar a guerra entre os povos e o ódio entre as religiões, culminado por "ideais" próprios de cada religião ou por más interpretações dos ensinamentos bíblicos.

Küng destaca dois aspectos na extenuante questão entre buscar-se a paz ou externar o choque entre as civilizações. Assim, são propostas duas marchas: uma que segue a política mundial, partindo de propulsões idealistas modernas; e, a outra, que vai da problemática objetiva da política mundial, partindo de eixos significativos que buscam o ethos mundial.

Na dimensão dos conflitos de política mundial, sobressai a responsabilidade global que cada um tem na busca pela paz entre as religiões. Segundo Küng, "Sem paz entre as religiões não haverá paz no mundo". Com base nesse eixo, vai chegar a um ponto em que as guerras deixarão de ser por motivos religiosos, e passarão, futuramente, a ser de civilizações, destacado por Huntington. 
que se observa é que a religião tem sido identificada como a força propulsora que move as ações e as convicções dos homens; força essa capaz de levá-los a dar a própria vida em nome dessa fé. A ciência política começou a perceber que isso tem ocasionado uma multipolaridade global, onde desta fazem parte a multiculturalidade e a multirreligiosidade.

Outros fatores perturbantes são os de causas políticas culturais e religiosas, visto que, subjacente ao conflito político externo, há os interesses de poder econômico, político e militar. Assim, podem estar ocultas as diferenças e rivalidades étnico-religiosas. Na proposta do ethos mundial, Küng (p. 212) diz que "[...] o futuro da paz e da civilização depende de que os líderes políticos e intelectuais das grandes culturas mundiais se entendam mutuamente e cooperem uns com os outros". Ou seja, a essência de cooperação consiste em obter um diálogo mútuo entre as grandes potências mundiais por meio de seus líderes.

Outra questão que segue esse contexto é a separação entre lgreja e Estado, acarretando, assim, a dimensão de conflito entre os dois eixos, visto que há situações que precisam ser consideradas política e religiosamente. $\bigcirc$ que se percebe é que é necessária a eficiência política de interesses, mas com 266 ética. De acordo com Küng, importa trabalhar uma ética voltada à responsabilidade que leve em conta todas as consequências.

Mas o que mantém uma sociedade unida? Essa é uma indagação que tanto o Estado como a Religião vem fazendo há séculos acerca do que se pode fazer para aproximar os povos em todo o mundo. Contudo, o autor frisa que a religião também separa as sociedades. Isso é percebido no fundamentalismo religioso, extremamente violento e sangrento, também tratado por radicalismo. Ambos são repressores e combatem qualquer tipo de expressão liberal que vá de encontro ao que a religião preza e, portanto, um problema mundial. Ainda há a questão do moralismo rigoroso, amplamente divulgado na variante do Opus Dei, que preza a cultura da vida e da morte. Ou seja, totalmente, contrário à liberdade de expressão, do princípio de ir e de vir e, principalmente, o de cidadania.

Portanto, o que pode manter uma sociedade unida, nas palavras de Küng, estaria no estabelecimento de um ethos vinculante, com um consenso básico sobre valores comuns, sobre normas e atitudes que inclua a autorrealização autônoma e a responsabilidade solidária. Ou seja, que possa ser 
vislumbrado um ethos libertador, vinculante, tolerante e mundial. E o melhor, é uma religião que obrigue o homem a ser mais humano e aberto para a dimensão do transcendente, do religioso, no intuito de se vislumbrar um ethos humanizado e transcendente entre as religiões. Com o estabelecimento de um elo de confiança entre as religiões e havendo motivação, isso poderá contribuir para a paz interna e individual, como também superar as agressões e a violência na sociedade. Enfim, o ideal é aproximar as religiões da Declaração Geral dos Direitos Humanos, buscando fundamentar as próprias tradições e pondo-as em prática. Assim, cada um terá o livre exercício da escolha da religião na busca do diálogo entre as minorias religiosas com visando à confiança.

Portanto, a paz mundial pode ser entendida por meio de um ethos total, isto é, um ethos que humaniza as pessoas a compreender uns aos outros, a respeitar as opiniões, a permitir o livre arbítrio de seguir ou não esta ou aquela religião, e, sobretudo, obedecendo a este ensinamento do ser supremo: amar uns aos outros. $\bigcirc$ princípio do diálogo deve ser mantido, como também da compreensão e da tolerância, na busca pela paz e no respeito aos credos, às opiniões e aos valores a que cada religião se propõe.

Enfim, as religiões contribuem para a expansão do ethos tolerante e mundial, não tendo superioridade entre uma e a outra, mas no bem-estar de todos os seres e destes com o transcendente. Embora possa ser designado por meio de vários nomes, é único, amando todos, nas mais diferentes línguas, ações e amor universal.

Assim, apesar de extensa a obra de Hans Küng, é bastante proveitosa, trazendo contribuições para as áreas de humanas - Filosofia, Sociologia, História, Teologia e outras - fundamentando estudos de pesquisadores, estudantes e adeptos à temática, que, apesar de complexa, é também curiosa e reflexiva no contexto atual. $\bigcirc$ autor aborda, com bastante maestria, a questão da paz como um desafio às religiões, tratando do tema com certa delicadeza e, às vezes, com apontamentos de detalhes, até um tanto pessoal, induzindo o leitor a pensar que todos têm a responsabilidade de agir para a qualidade de vida, no bem-estar social e, principalmente praticar ações humanizadoras. A paz no mundo consiste no estabelecimento das ações humanas, ou seja, no cuidado com o próximo, no pensar antes de agir, no praticar o bem sem olhar a quem, independentemente de cultura, de pessoa, de raça, de credo, mas, simplesmente, o de se pôr no lugar do outro. São esses fundamentos que constam em todas as religiões, porém, por questões pequenas, fúteis, são 
esquecidas no dia a dia e a paz se perde. Enfim, a obra demonstra a força mediante a cooperação mútua entre as importantes potências políticas e intelectuais das grandes culturas mundiais.

Profa. Ms. Elisângela de Carvalho Franco Instituto Federal de Educação, Ciência e Tecnologia de Rondônia Integrante do Grupo de pesquisa Estudos em Educação, Filosofia, Tecnologias

Recebido 22 set. 2015

Aceito 30 out. 2015 